\title{
Европейский Конкурс по правам человека им. Рене Кассена и вопросы защиты прав человека в России
}

\author{
Юрьев M.E.*
}

Весной 2004 г. во Франции (г. Страсбург) отметит свой 20-летний юбилей Европейский Конкурс по правам человека им. Рене Кассена**, в работе которого планируется участие более 60 международных команд, представляюших крупнейшие университеты и известные правовые школы стран Европы, США и Канады.

Организатором Конкурса выступает французская Ассоциация Juris Ludi, которая совместно с Университетом Р. Шумана, Международным институтом защиты прав человека (г. Страсбург), при поддержке французского правительства, региональных властей и мэрии г. Страсбурга под эгидой Совета Европы осуществляет с 1985 г. работу по организации и проведению международных модельных игр в области защиты прав человека.

Среди постоянных участников данного Конкурса следует назвать, прежде всего, такие крупнейшие западные университеты как Париж I (Сорбонна), Королевский Колледж Лондонского Университета (King's College), Вашингтонский университет, Римский Институт международных отношений, Гёте Институт (Франкфурт-на-Майне), Институт Робера Шумана, Институт политических наук (г. Страсбург) и др., которые в разные годы его проведения занимали призовые места по проблемам зашиты окружаюшей среды, защиты национальных меньшинств, частной жизни, интеллектуальной собственности, свободы СМИ и др., демонстрируя высокое качество подготовленных материалов и высокий уровень выступлений в Суде.

* Юрьев М.Е. - аспирант кафедры европейского права МГИМО (У) МИД России, магистр юриспруденции.

** Рене Кассен - один из авторов Всеобщей декларация прав человека, крупнейший французский юрист, который впоследствии занимал пост председателя Европейского суда по правам человека и был удостоен за свою деятельность Нобелевской премии мира. 
Для России участие в этом престижном международном форуме имеет важное значение. Происходящие в последние годы реформы законодательства и судебной системы отчетливо свидетельствуют о том, что Россия все в большей мере стремится соответствовать стандартам Совета Европы в области защиты прав человека, укреплять основные демократические институты и обеспечивать эффективную защиту прав и свобод человека, создавая, таким образом, прочные союзнические отношения с Европейским Союзом и всеми европейскими странами для включения ее в единое европейское пространство.

В течение последних семи лет Россия была представлена на конкурсе командами университета МГИМО МИД России и университета г. Ростов-на-Дону.

\section{Цели и задачи конкурса}

Конкурс им. Рене Кассена является одной из самых значительных международных модельных игр по практике Европейского Суда по правам человека, существующих в настоящее время в Европе. Он предоставляет уникальную возможность студентам-участникам не только продемонстрировать полученные за время учебы в университетах знания, публично выступая в Европейском Суде, но и глубоко проникнуться духом защиты прав человека, стать «бойцами за права человека», как этого желал Р. Кассен.

Одна из главных целей Конкурса состоит в расширении и углублении знаний по правам человека, в поощрении изучения студентами Европейской Конвенции о защите прав человека и основных свобод, механизма работы и практики Европейского Суда.

Организаторы конкурса стремятся развить у его участников способности применять и толковать нормы права в области защиты прав человека, а также помочь приобрести определенные навыки профессиональных выступлений перед широкой аудиторией, совершенствовать систему юридической защиты прав и свобод человека посредством эффективного использования международного и сравнительного права, оказать помощь будущим адвокатам, судьям и юристам в применении норм международного права в международных, региональных и национальных судебных инстанциях.

Широкой юридической общественности и рядовым гражданам России Конкурс дает возможность подробно ознакомиться с общеев- 
ропейскими стандартами, которым должна в полном объеме соответствовать правовая система Российской Федерации, ибо сформированный Конвенцией правовой порядок становится частью правовой системы Российской Федерации.

Bсе российские граждане, а также другие лица, находящиеся под ее юрисдикцией, получают возможность строить свою зашиту в судах непосредственно на положениях Конвенции и обжаловать затрагивающие их решения национальных инстанций в международных органах.

Конкурс дает ключ к пониманию того, как лучше и эффективнее отстаивать свои неотъемлемые права и интересы внутри страны, а в случае неудачи - как добиваться их судебной защиты на международном уровне.

\section{Условия проведения конкурса}

Конкурс им. Рене Кассена является моделью разбирательства максимально приближенного к реальным условиям конкретного дела, связанного с нарушением прав граждан вымышленного государства.

Предложенная для обсуждения тема основывается на реальных проблемах сегодняшнего дня и отражает определенный уровень обеспокоенности европейской и мировой общественности развитием той или иной конкретной проблемы. В чистом виде не рассматривается ни одно конкретное дело из практики Европейского Суда, однако наиболее характерные случаи нарушения прав человека, взятые из различных дел, фигурируют в рассматриваемом деле.

Участником Конкурса может быть любой университет, который разделяет идею конкурса и условия его проведения, помещенные на официальном сайте Ассоциации.

Конкурс состоит из двух этапов. На первом этапе, согласно Регламенту, каждая из команд должна представить письменное обоснование своей позиции (меморандума) на французском языке. Согласно жребию ей надлежит отстаивать либо сторону заявителя, либо государства. В зависимости от качества подготовленного меморандума жюри выставляет командам соответствующее количество баллов, которые впоследствии учитываются при окончательном подведении итогов.

Суть рассматриваемой проблемы, методы ее правового регулирования, процессуальные аспекты рассматриваемого дела формулируются на основе подбора и изучения всевозможных документов, судебных 
решений, докладов и рекомендаций органов Совета Европы, а также специализированной литературы, обосновывающей позицию стороны.

Особенность конкурса им. Рене Кассена состоит в том, что все подготовленные командами письменные материалы (меморандум), а также устные выступления участников во время публичных слушаний в Суде должны быть сделаны исключительно на французском языке.

Команда состоит из студентов 3-5 курсов университетов, специализирующихся по проблемам защиты прав человека и не имеющих права повторного участия. Организаторы конкурса видят в этом возможность оценить не только студентов, но и сами университеты и правовые школы. С этими требованиями организаторов можно согласиться, ибо участие в конкурсе и более детальное изучение в связи с этим документов Совета Европы имеют действительно неоспоримую практическую ценность как для студентов, непосредственно участвующих в Конкурсе, так и в целом для университетов, правовых школ, формирующих будущих юристов, адвокатов, специалистов в области защиты прав человека. Как показывает практика, контрольные механизмы Конвенции довольно эффективны, и их надо хорошо знать.

В самом деле, использование этих механизмов в совокупности с высоким профессионализмом правоведов позволяет государствамучастникам активнее вести работу по совершенствованию национального правового порядка, ориентируясь на общеевропейские стандарты. Оно вынуждает соответствующие власти вносить необходимые изменения в законодательство и практику. Все это позволяет рассчитывать на возможность приведения национального законодательства в соответствие с общеевропейским и оказывать, таким образом, нужное влияние на проведение правовых реформ.

Второй этап состоит из устных разбирательств дела и проходит в зале заседаний Европейского Суда. В число членов жюри, оценивающих выступления команд, приглашаются лица, профессионально занимающиеся вопросами защиты прав человека в научном и практическом планах, представляющие различные правовые системы, ответственные сотрудники различных департаментов Совета Европы, судьи Европейского Суда.

Опираясь на положения Европейской Конвенции о защите прав человека и основных свобод, практику Европейского Суда, команды отстаивают позиции, изложенные в меморандуме, отвечают на много- 
численные вопросы Председателя и членов жюри. Судьями оцениваются не только суть позиции сторон, но и умение отвечать на любые относящиеся к делу вопросы, демонстрировать доскональное знание ЕКПЧ, конкретных дел Европейского Суда, умение полемизировать с оппонентами в рамках предусмотренных Регламентом правил. За исключением полуфиналов и финала судьи не выносят решения в пользу одной из сторон: в их задачу входит только оценка устного выступления участников, основанного на подготовленных письменных материалах. В первую очередь оценке подлежит умение убедительно изложить сильные аргументы в отношении зашищаемой позиции и квалифицированно интерпретировать в свою пользу ее неоднозначные моменты, слабые или спорные аспекты. Судьями оцениваются также ораторское мастерство выступающих, точность и образность языка, что находит свое выражение в предоставлении дополнительных баллов каждому выступающему отдельно.

Финальное выступление проходит в присутствии всех участников Конкурса. Победителям вручаются дипломы и различные премии, их приглашают на практику в структуры Европейского Суда по правам человека, институты Европейского Союза, другие специализированные организации.

Фабула дела Конкурса 2003 г. была посвящена важной и актуальной теме защиты прав и свобод ребенка, охраны семьи как «первичной ячейки общества», изменения правового статуса несовершеннолетних путем наделения их дополнительными гражданскими правами в свете произошедших в последние десятилетия в Европе глубоких социально-экономических преобразований.

Участниками подробно рассматривались такие вопросы, как дееспособность физических лиц, гражданские права и обязанности несовершеннолетних, в частности, право на доступ в суд, способы признания отцовства, установления юридической связи между внебрачным ребенком и его родителями, юридические последствия отказа от детей и их усыновления. Поднимались вопросы пределов допустимого вмешательства СМИ в частную жизнь семьи, ребенка. Эти проблемы рассматривались в контексте обсуждения возможности принятия в рамках Совета Европы дополнительного протокола к ЕКПЧ, призванного решить вопрос о правах несовершеннолетних и признании их в качестве субъектов права. 


\section{Подготовка команд}

Участие в международном конкурсе им. Рене Кассена наводит на мысль о необходимости внесения некоторых корректив в систему подготовки наших юридических кадров, что позволит молодым юристам лучше понять основные правовые идеи и тенденции современности и подготовить их к работе в условиях занятия Россией достойного места в европейском и мировом Сообществе.

Речь в данном случае идет не о реформе тех исторически сложившихся и оправдавших себя систем, форм и методов преподавания, а также существующих на сегодняшний день в наших университетах дисциплин, а об их определенной реорганизации и актуализации, более углубленном их изучении, добавлении к ним новых дисциплин, судебной практики. Представляется необходимым не только дальнейшее совершенствование системы юридического образования, но и формирование новой системы мышления юриста.

Юрист, адвокат, судья, изучающий европейское право и занимающийся защитой прав человека, безусловно, должны не только в совершенстве владеть европейскими языками, но и уметь на практике демонстрировать свои углубленные профессиональные знания по конкретным юридическим дисциплинам на этих языках.

Изучение международного права должно не ограничиваться лишь проработкой учебной литературы, а позволить на практике использовать полученные фундаментальные знания, демонстрируя их в честной, открытой конкурентной борьбе на национальных и международных форумах. Это усовершенствовало бы необходимый методологический инструментарий для эффективного изучения студентами европейского права.

Сегодня на фоне все большей гармонизации права Европейского Союза в ряде западноевропейских стран, в частности во Франции, в Германии, и в других, читаются такие специальные предметы, как сравнительное конституционное, административное, гражданское, уголовное право. Сушествуют институты сравнительного права, где оно преподается в сравнении с правом других государств в целом, а также по отраслям. Таким образом, право видится в контексте европейских и мировых достижений в этой области.

Опыт участия в международных конкурсах, в частности в Конкурсе им. Рене Кассена, показывает, что главным достоинством высшего 
правового образования в наиболее развитых европейских странах являются открытость, доступность, углубленная специализация, высокая техническая оснашенность, наличие компьютеризированных и хорошо систематизированных законодательных баз данных.

Однако, как показывает практика, зачастую эти знания нивелируются субъективизмом научных школ, чрезмерно узкой специализацией и недостаточной инициативой молодых специалистов. Предпочтение отдается скорее имеющемуся прецеденту, нежели поиску оригинального решения проблемы, к чему более подготовлены наши молодые юристы.

В целом, можно с удовлетворением отметить, что юридическое образование в России характеризует бульшая фундаментальность, наличие обязательных универсальных классических дисциплин, преподаваемых в соответствии с обязательной программой, что обеспечивает высокий уровень базовых знаний. К этому следует также добавить, что частые изменения российского законодательства, принятие новых законов, вынуждает наших юристов более творчески подходить к решению возникающих проблем и делает их более гибкими, учитывающими указанные обстоятельства.

В связи с этим опыт современного европейского права, обучающие материалы и специальное программное обеспечение, которыми могут воспользоваться наши юристы, приобретает особое значение.

\section{Практические выводы участия в конкурсе}

Представляется, что при подготовке команд к конкурсу следовало бы сосредоточить основное внимание на следующих направлениях: обеспечить овладение студентами юридических вузов более углубленными профессиональными знаниями иностранных языков, а также латыни; шире давать элементы сравнительного европейского и международного права в процессе преподавания различных отраслей национального права; активнее использовать новейшие технологии, законодательные базы данных; распространять практику проведения модельных игр с привлечением высококвалифицированных специалистов в области юриспруденции, судебной практики; активнее участвовать в международных конкурсах, встречах и форумах по проблемам защиты прав человека. 
В методологическом плане подготовка к конкурсу должна быть построена на всестороннем изучении материалов контрольных органов Конвенции, знакомстве с решениями Европейского Суда применительно к конкретным ситуациям, ибо система европейской защиты прав человека не сможет действовать эффективно, если судебная практика в Страсбурге не будет широко известна лицам, практикуюшим право в государствах, подписавших Конвенцию, в частности, судьям.

И хотя в разных государствах существуют различные механизмы учета этих решений в текущем законодательстве, правоприменительной практике и системе переподготовки судебных кадров и кадров государственных чиновников, тем не менее, следует признать, что в Европе сложилась норма международного права, согласно которой совокупность решений контрольных органов Конвенции рассматривается в качестве прецедентного права в области защиты прав человека и основных свобод. И именно эти аспекты должны постоянно быть в поле зрения наших студентов, изучаюших вопросы международноправового регулирования защиты прав человека.

Эффективная подготовка российских студентов к Конкурсу видится также в детальном изучении сферы действия Европейской Конвенции, порядка обращения в Европейский Суд, изучении соотношения между требованиями Конвенции и внутренним правом государств-участников, других международно-правовых систем. Это особенно важно для наших студентов в контексте понимания особенностей англо-американского правового мышления и специфики прецедентного права.

Опыт знакомства с практикой Европейского Суда показывает, что в целом основанный ЕКПЧ механизм правовой зашиты обеспечивает высокий уровень защиты прав человека в Европе и, более того, является определенным стандартом их защиты не только в Европе, но и во всем мире.

Много интересного и полезного для подготовки команд содержит литература по правам человека, включаюшая монографии и различного рода комментарии ведуших европейских и российских специалистов в области защиты прав человека. Большим плюсом в работе над составлением меморандума является изучение и применение к материалам дела недавно рассмотренных, но еше не опубликованных решений Европейского Суда, содержащихся на его официальном сайте. 
Важную роль играет и самостоятельная подготовка участников конкурса, ведь именно от них зависит то, как они смогут представить изученный и подготовленный ими материал.

Наконец, полезной является организация дискуссий по материалам рассматриваемого дела, которые можно было бы изучать в рамках специализированных занятий по курсу «Европейская система защиты прав человека». Желательно проводить занятия на французском языке, на которых обсуждались бы не только теоретические вопросы применения Европейской Конвенции, но и организовывались бы дискуссии со студентами на основе материалов рассматриваемого дела, что позволило бы им на устных публичных выступлениях быть готовым к любым возможным вопросам.

Хотелось бы еше раз отметить, что Европейский конкурс по правам человека им. Рене Кассена является одной из обучающих программ, способствующих более углубленному изучению проблем защиты прав человека. Основная его задача нам видится в создании условий профессионального общения представителей различных правовых систем и школ, позволяющих осуществлять обмен и взаимопроникновение современных юридических идей и методов по защите прав человека.

Развитие такого диалога способствует более углубленному общению между юристами различных государств, формирует единообразные подходы к решению профессиональных проблем, создает предпосылки для сближения подчас противоположных позиций, приводит к более глубокому и всестороннему международному взаимопониманию и сотрудничеству, укрепляет и совершенствует нашу правовую систему, ее ценности и идеалы, значительно усиливает связь с правовыми системами других государств. 